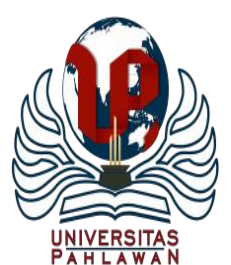

Edukatif : Jurnal Ilmu Pendidikan Volume 3 Nomor 6 Tahun 2021 Halm 3697 - 3703

EDUKATIF: JURNAL ILMU PENDIDIKAN

Research \& Learning in Education

https://edukatif.org/index.php/edukatif/index

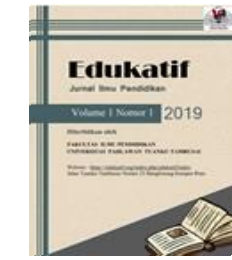

\title{
Pengaruh Model Pembelajaran Picture And Picture terhadap Kemampuan Berpikir Kreatif Siswa di Sekolah Dasar
}

\author{
Novita Pratiwi ${ }^{1 凶}$, Aslam $^{2}$ \\ Universitas Muhammadiyah Prof. DR. Hamka, Indonesia ${ }^{1,2}$ \\ E-mail : pratiwi.novita1811@ gmail.com ${ }^{1}$, ea_aslam@uhamka.ac.id ${ }^{2}$
}

\begin{abstract}
Abstrak
Penelitian ini bertujuan untuk melihat pengaruh dalam penggunaan model pembelajaran Picture and Picture terhadap kemampuan berpikir kreatif siswa pada pembelajaran IPA di SD. Dalam penelitian ini, metode yang digunakan yaitu metode kuantitatif, metode penelitian menggunakan Quasi Experimental Desaign, dan desain penelitian nya yaitu Nonequivalent Control Group Desaign. Subjek dalam penelitian ini berjumlah 60 orang yang terbagi menjadi dua kelas yaitu kelas IV A sebagai kelas kontrol dan IV B sebagai kelas eksperimen dimana jumlah masing-masing siswa 30 orang. Teknik pengumpulan data yang dipilih yaitu menggunakan lembar observasi, tes formtaif, dan dokumentasi. Hasil penelitian menunjukkan adanya pengaruh dari penggunaan model pembelajaran Picture and Picture. Hal ini dapat dilihat dari adanya peningkatan nilai pretest dan post-test, selain itu pada uji normalitas dan juga homogenitas menunjukkan bahwa hasil yang didapat normal. Maka dapat disimpulkan bahwa dengan menggunakan model pembelajaran Picture and Picture dapat memberikan pengaruh dalam meningkatkan kemampuan berpikir kreatif siswa di SD pada pembelajaran IPA, karena penggunaan model pembelajaran membuat variasi di kelas sehingga siswa lebih semangat dalam belajar.
\end{abstract}

Kata Kunci: Picture and Picture, Kemampuan Berpikir Kreatif, IPA.

\section{Abstract}

This research aims to know the effect of using the Picture and Picture learning model on students' creative thinking skills in science learning in elementary school. The method in this research used the quantitative approach, the research method uses Quasi-Experimental Design, and the research design is the Nonequivalent Control Group Design. The subjects in this research were 60 students divided into two classes, class IV A as the control class and IV B as the experimental class with 30 students. Data collection techniques using observation sheets, formative tests, and documentation. The results showed that there was an influence from the use of the Picture and Picture learning model. This can be seen from the increase in the pre-test and post-test scores, in addition to the normality and homogeneity tests, which shows that the results obtained are normal. So it can be concluded that using the Picture and Picture learning model can influence in improving students' creative thinking skills in elementary school in science learning because the use of learning models makes variations in class so students are more enthusiastic in learning.

Keywords: Picture and Picture, Creative Thinking Skills, Science Learning.

Copyright (c) 2021 Novita Pratiwi, Aslam

$\square$ Corresponding author

Email : pratiwi.novita1811@gmail.com

DOI : https://doi.org/10.31004/edukatif.v3i6.1081 
3698 Pengaruh Model Pembelajaran Picture And Picture terhadap Kemampuan Berpikir Kreatif Siswa di Sekolah Dasar - Novita Pratiwi, Aslam

DOI: https://doi.org/10.31004/edukatif.v3i6.1081

\section{PENDAHULUAN}

Wabah Covid-19 saat ini masih mendominasi ruang publik. Covid-19 atau yang dikenal dengan nama virus corona adalah penyakit yang menyerang sistem pernapasan. Corona virus menular dengan sangat cepat, virus ini semula berasal dari kota Wuhan dan pada saat ini sudah menginfeksi berbagai negara termasuk Indonesia. Virus Covid-19 ini bisa menyerang orang-orang segala usia mulai dari bayi hingga orang dewasa serta lansia. Akibat dari penyebaran wabah Covid-19 ini, berbagai negara menerapkan sistem yang berbedabeda untuk menekan penyebaran virus Covid-19. Pemerintah Indonesia mengeluarkan kebijakan agar masyarakat melakukan kegiatan dari rumah. Hal ini juga berdampak pada sistem pembelajaran di Indonesia yang dilaksanakan dengan metode daring.

Pembelajaran secara daring merupakan gaya belajar baru dalam kegiatan pembelajaran dengan memanfaatkan berbagai perangkat elektronik yang tersambung dengan internet selama penyampaian materi berlangsung (Rigianti, 2020). Penyampaian pembelajaran daring dengan web ini lebih interaktif. Mekanisme pembelajaran daring tidak memiliki batasan akses, sehingga memungkinkan apabila pembelajaran dilakukan dengan mengguanakan lebih banyak waktu (Suhery et al., 2020). Badan pemerintah seperti contohnya sekolah, memanfaatkan media sosial agar dapat berinteraksi dengan para pemangku kepentingan, walaupun terdapat tantangan terkait dengan privasi, keamanan, pengelolaan data, aksesibilitas, inklusi sosial, tata kelola, dan masalah kebijakan informasi lainnya (Aslam et al., 2020). Pemerintah turut berperan dalam memproses ketimpangan dalam kegiatan belajar-mengajar selama pandemi Covid-19. Dalam laman resmi Kemendikbud RI memberitakan 12 aplikasi yang dapat digunakan oleh murid di rumah yaitu (1) Rumah belajar; (2) Meja kita; (3) Icando; (4) Indonesiax; (5) Google for education; (6) Kelas pintar; (7) Microsoft office 365; (8) Quipper school (9) Ruang guru; (10) Sekolahmu; (11) Zenius; (12) Cisco webex (Handarini, 2020).

Pembelajaran IPA di SD adalah pembelajaran yang berkaitan dengan alam sekitarnya untuk menambah pengetahuan siswa, dan melakukan beberapa kegiatan ilmiah sebagai bagian dari pengalaman (Galuh et al., 2018). Maksud adanya pembelajaran IPA di SD untuk : a. Menyampaikan kepada siswa pengetahuan yang berkenaan dengan bumi tempat mereka tinggal dan cara bersikap. b. Menumbuhkan sikap hidup ilmiah. c. Mengajarkan keterampilan dalam melakukan pengamatan. d. Membimbing siswa agar dapat mengenal, menghargai dan mengerti hasil dari para ilmuan. e. Mengaplikasikan metode ilmiah dalam mengatasi masalah (Ida, 2016). Dalam pembelajaran IPA menghafal atau mendengarkan guru menjelaskan saja tidak cukup bagi siswa, namun siswa patut untuk mengerjakan percobaan sebagai proses dari belajar, observasi atau eksperimen akan membantu pembentukan kreativitas siswa dan upaya menjaga, merawat, serta membenahi kerusakan alam yang terjadi berguna untuk membentuk sikap ilmiah yang bertujuan untuk menjaga kestabilan alam secara baik agar tetap lestari (Sulthon, 2016).

Pembelajaran dapat dikatakan efektif apabila terdapat perubahan pada diri orang tersebut, misalkan yang tidak tahu menjadi tahu. Belajar merupakan proses yang terjadi pada individu melalui proses interaksi dengan lingkungannya sehingga terjadi pengalaman dalam belajar (Lufri et al., 2020, p. 16). Pembelajaran merupakan kegiatan mentransfer ilmu pengetahuan, kepandaian dan tabiat, serta membentuk sikap dan rasa percaya diri pada peserta didik (Suardi, 2018, p. 7). Ada beberapa faktor yang dapat menunjang keberhasilan dalam proses pembelajaran, antara lain faktor internal dan eksternal. Faktor internal antara merupakan faktor yang ada pada dalam diri siswa, seperti minat, bakat, dan motivasi. Sedangkan faktor eksternal adalah faktor lingkungan yang ada disekitar peserta didik, contohnya yaitu sekolah, orang tua, dan lingkungan masyarakat. Sekolah sebagai salah satu faktor eksternal dalam menunjang keberhasilan proses pembelajaran hendaknya memberikan fasilitas yang nyaman dan layak kepada siswa agar dapat mengikuti pelajaran dengan baik. Guru juga berperan penting dalam kegiatan pembelajaran agar dapat memberikan hasil yang maksimal bagi siswa. Guru sebagai pengajar dan pendidik diharapkan dapat menciptakan suasana pembelajaran menjadi menyenangkan sehingga apa yang ingin diajarkan kepada siswa dapat tersampaikan dengan baik. 
Selama pembelajaran daring ada beberapa kendala, kendala pertama bila siswa merasakan kebosanan, guru harus memikirkan strategi bagaimana caranya supaya anak-anak bisa keluar dari zona kebosanan mereka. Guru harus kreatif dalam menciptakan pembelajaran daring yang menarik bagi siswa (Anugrahana, 2020). Guru dapat menggunakan model pembelajaran sebagai salah satu pilihan alternatif untuk menunjang kegiatan pembelajaran agar semakin menyenangkan bagi peserta didik. Model pembelajaran merupakan strategi yang digunakan guru untuk meningkatkan motivasi belajar, sikap belajar di kalangan siswa, mampu berpikir kritis, memiliki keterampilan sosial, dan pencapaian hasil pembelajaran yang lebih (Hanna, 2015). Dapat dikatakan model pembelajaran adalah penerapan yang berisikan metode, strategi, dan tehnik pembelajaran. Model pembelajaran bermanfaat sebagai acuan atau pedoman rancangan yang dapat digunakan pendidik pada saat kegiatan pembelajaran.

Guru dapat menggunakan berbagai model pembelajaran yang kreatif dan inovatif. Salah satu model pembelajaran yang dapat digunakan yaitu picture and picture. Model pembelajaran Picture and Picture dapat diterapkan pada siswa SD sebagai penunjang kegiatan pembelajaran agar lebih menyenangkan dan menciptakan interaksi antara guru dan siswa. Model pembelajaran picture and picture merupakan contoh salah satu model pembelajaran yang kooperatif dengan mementingkan kelompok belajar (Wiyati, 2018). Model pembelajaran Picture and Picture merupakan salah satu dari sekian banyak model pembelajaran yang menggunakan gambar sebagai media yang dapat diperoleh dari sumber buku, majalah, internet dan foto sesuai dengan materi dan tujuan pembelajaran (Jariah, 2016). Adapun kelebihan kelebihan model pembelajaran Picture and Picture yaitu: 1) Siswa lebih mudah menguasai materi karena guru menampilkan gambar berdasarkan materi yang diajarkan. 2) Meningkatkan daya pikir siswa karena guru meminta siswa untuk menganalisis gambar yang ada. Pembelajaran lebih berkesan karena siswa terlibat secara langsung (Widyawati, 2019).

Model pembelajaran ini dapat membantu siswa untuk dapat berpikir secara logis, dan melatih keberanian siswa untuk berbicara atau mengungkapkan pemahaman sendiri. Terlebih lagi dalam pembelajaran Kurikulum 2013 siswa dituntut untuk dapat berpikir kritis dan juga kreatif, sehingga peneliti berharap dengan adanya model pembelajaran ini dapat mengasah kemampuan berpikir siswa dalam kegiatan pembelajaran. Implementasi Kurikulum 2013 memiliki tujuan untuk mempersiapkan manusia Indonesia agar memiliki kemampuan hidup sebagai pribadi dan warga negara yang beriman, produktif, kreatif, inovativ, serta mampu berkontribusi kepada masyarakat, bangsa, negara dan peradaban dunia (Yusuf, 2018). Pengertian dari berpikir kreatif yaitu sebagai proses menghasilkan produk baru yang inovatif, hal tersebut berasal dari kegiatan yang telah terarah sesuai tujuan yang telah ditentukan (Asri, 2019). Kemampuan berpikir kreatif sebagai kunci keberhasilan dalam pemecahan masalah, karena kreativitas dapat menjembatani tahap pengelolaan kognitif agar orang tersebut memiliki prestasi atau hasil yang meyakinkan (Lulu et al., 2016).

Menurut pengamatan peneliti di SDN Baru 07 Pagi Cijantung, proses pembelajaran daring dinilai kurang efektif karena guru kurang memanfaatkan media, model, atau metode yang bervariasi, pembelajaran lebih banyak berpusat pada guru (Teacher's Center), sehingga siswa tidak banyak dilibatkan selama proses pembelajaran. Akibatnya siswa terlalu pasif pada saat kegiatan pembelajaran, terlebih pada saat diberikan tugas oleh guru ada beberapa siswa yang tugasnya dikerjakan oleh orang tua karena siswa terlalu malas untuk berpikir. Untuk itu peneliti menggunakan model pembelajaran picture and picture dengan harapan dapat mengasah kemampuan berpikir kreatif siswa, dan membuat suasana pembelajaran daring menjadi lebih menyenangkan bagi siswa.

Pada penelitian sebelumnya yang dilakukan oleh (Siti et al., 2020) dengan judul "Pengaruh Model Pembelajaran Picture and Picture terhadap Hasil Belajar Geografi" yang menuliskan bahwa terdapat perbedaan hasil belajar yang signifikan antara kelas eksperimen yang diberi perlakuan model pembelajaran picture and picture dan kelas kontrol yang menggunakan model pembelajaran konvensional, maka dapat ditarik kesimpulan bahwa Penggunaan model pembelajaran picture and picture terbukti dapat meningkatkan 
hasil belajar kognitif peserta didik. Dalam penelitian ini peneliti menggunakan model yang sama seperti penelitian yang telah dilakukan sebelumnya yakni picture and picture akan tetapi berbasis online dengan menggunakan Google Meet sebagai aplikasi bantu pembelajaran, dan juga model pembelajaran picture and picture disajikan dalam bentuk Microsoft Power Point. Model pembelajaran ini melatih peserta didik dalam berpikir kreatif, logis, dan juga sistematis.

Berdasarkan uraian yang telah dipaparkan di atas, maka peneliti tertarik untuk mengambil penelitian mengenai pengaruh model pembelajaran Picture and Picture terhadap kemampuan berpikir kreatif siswa SD dalam pembelajaran IPA berbasis online. Tujuan penelitian ini yaitu untuk mengetahui pengaruh kemampuan berpikir kreatif dengan menggunakan model pembelajaran picture and picture pada siswa kelas IV SDN Baru 07 Pagi Cijantung.

\section{METODE PENELITIAN}

Metode penelitian yang digunakan yaitu metode kuantitatif. Penelitian dengan metode kuantitatif ialah penelitian yang terstruktur, dan memerlukan hasil data kuantitatif untuk dapat dihitung dan disimpulkan (Agung \& Zarah, 2016). Pada penelitian ini, desain metode penelitian yang digunakan adalah Quasi Experimental Desaign. Desain ini mempunyai kelompok kontrol, tetapi tidak dapat berfungsi sepenuhnya untuk mengontrol variabel-variabel luar yang mempengaruhi pelaksanaan eksperimen (Sugiyono, 2013, p. 77). Bentuk desain penelitian yang akan digunakan yaitu Nonequivalent Control Group Desaign. Peneliti menggunakan dua kelompok kelas yaitu kelas eksperimen dan kelas kontrol. Kelas eksperimen akan diberikan perlakuan dengan menggunakan model pembelajaran picture and picture, sedangkan pada kelas kontrol tidak akan diberikan perlakuan.

Populasi adalah wilayah yang tediri dari objek/subjek yang memiliki kualitas serta karakteristik tertentu sehingga dapat dipelajari dan dibuat kesimpulan (Sugiyono, 2013). Populasi dalam penelitian ini mencakup seluruh siswa kelas IV SDN Baru 07 Pagi Cijantung tahun ajaran 2020/2021 yang terbagi menjadi kelas IV A dan IV B. Jumlah seluruh siswa kelas IV SDN Baru 07 Pagi Cijantung yaitu 60 orang. Untuk teknik pengumpulan datanya menggunakan lembar tes objektif pilihan ganda, lembar observasi, dan dokumentasi. Kemudian teknik analisis data menggunakan uji liliefors untuk menguji normalitas, dan uji $\mathrm{F}$ (Varians) untuk menguji homogenitas. Untuk uji hipotesis, peneliti memilih uji-t dengan taraf signifikansi 5\% atau $(\alpha=0,05)$.

\section{HASIL DAN PEMBAHASAN PENELITIAN}

Uji normalitas dibutuhkan untuk menguji apakah data berdistribusi normal atau tidak. Berikut ini hasil perhitungan data uji normalitas :

Tabel 1. Hasil Uji Normalitas

\begin{tabular}{ccccc}
\hline \multirow{2}{*}{ Kelas } & \multicolumn{2}{c}{ Nilai $\mathbf{L}_{\text {hitung }}$} & \multirow{2}{*}{ Nilai $\mathbf{L}_{\text {tabel }}$} & \multirow{2}{*}{ Kriteria } \\
\cline { 2 - 3 } & Pre-Test & Post-Test & & \\
\hline Eksperimen (IV B) & 0,105 & 0,120 & \multirow{2}{*}{0,162} & \multirow{2}{*}{ Normal } \\
\hline Kontrol (IV A) & 0,120 & 0,140 & & \\
\hline
\end{tabular}

Untuk uji normalitas kali ini menggunakan uji liliefors dengan taraf signifikan $\alpha=0,05$. Kriteria pengujian data berdistribusi normal apabila $\mathrm{L}_{\text {hitung }}<\mathrm{L}_{\text {tabel, }}$ dan data tidak berdistribusi normal apabila $\mathrm{L}_{\text {hitung }}>$ $\mathrm{L}_{\text {tabel. }}$. Nilai $\mathrm{L}_{\text {tabel }}$ didapatkan sebesar 0,162 dan berdasarkan dari hasil perhitungan yang ada pada tabel di atas, nilai $\mathrm{L}_{\text {hitung }}$ yang didapat lebih kecil dari $\mathrm{L}_{\text {tabel }}$ yaitu 0,162 maka dapat disimpulkan bahwa data berdistribusi normal. 
3701 Pengaruh Model Pembelajaran Picture And Picture terhadap Kemampuan Berpikir Kreatif Siswa di Sekolah Dasar - Novita Pratiwi, Aslam

DOI: https://doi.org/10.31004/edukatif.v3i6.1081

Tabel 2. Hasil Uji Homogenitas

\begin{tabular}{ccccc}
\hline \multirow{2}{*}{ Kelas } & \multicolumn{2}{c}{ Nilai F $_{\text {hitung }}$} & \multirow{2}{*}{ Nilai F $_{\text {tabel }}$} & \multirow{2}{*}{ Kriteria } \\
\cline { 2 - 3 } & Pre-Test & Post-Test & & \\
\cline { 1 - 1 } Eksperimen (IV B) & 1,72 & 1,75 & 1,85 & \multirow{2}{*}{ Homogen } \\
\hline Kontrol (IV A) & & & & \\
\hline
\end{tabular}

Setelah melakukan uji normalitas, tahap selanjutnya yang dilakukan yaitu uji homogenitas yang menggunakan uji Fisher dengan kriteria pengujian data $\mathrm{F}_{\text {hitung }}>\mathrm{F}_{\text {tabel }}$ maka $\mathrm{H}_{0}$ ditolak atau data tidak bersifat homogen, namun jika data yang menunjukkan bahwa $\mathrm{F}_{\text {hitung }}<\mathrm{F}_{\text {tabel }}$ maka $\mathrm{H}_{0}$ diterima atau data bersifat homogen. Sebagaimana yang telah tertera pada tabel di atas, maka semua data bersifat homogen karena nilai $F_{\text {hitung }}>F_{\text {tabel }}$.

Tabel 3. Hasil Uji Hipotesis

\begin{tabular}{ccccc}
\hline \multirow{2}{*}{ Kelas } & \multicolumn{2}{c}{ Nilai thitung } & \multirow{2}{*}{ Nilai ttabel } & \multirow{2}{*}{ Kriteria } \\
\cline { 2 - 3 } & Pre-Test & Post-Test & & \\
\cline { 1 - 1 } Eksperimen (IV B) & 4,44 & 8,53 & 2,00 & $\mathrm{H}_{1}$ diterima \\
\cline { 1 - 2 } Kontrol (IV A) & & & &
\end{tabular}

Langkah terakhir yaitu melakukan uji hipotesis menggunakan uji t pada taraf signifikan $\alpha=0,05$ dengan kriteria pengujian apabila $t_{\text {hitung }}>t_{\text {tabel }}$ maka $\mathrm{H}_{0}$ ditolak dan $\mathrm{H}_{1}$ diterima, namun apabila data yang didapatkan menunjukkan $\mathrm{t}_{\text {hitung }}<\mathrm{t}_{\text {tabel }}$ maka $\mathrm{H}_{0}$ diterima dan $\mathrm{H}_{1}$ ditolak. Jika dilihat pada tabel yang telah disajikan di atas, kedua nilai $t_{\text {hitung }}$ lebih besar dibandingkan nilai $\mathrm{t}_{\text {tabel }}$ baik itu untuk nilai pre-test maupun post-test. Maka $\mathrm{H}_{0}$ ditolak dan $\mathrm{H}_{1}$ diterima, yang mana artinya terdapat pengaruh penggunaan model pembelajaran picture and picture terhadap kemampuan berpikir kreatif siswa SD dalam pembelajaran IPA.

Tabel 4. Perbandingan Nilai Rata-rata Kelas Eksperimen dan Kelas Kontrol

\begin{tabular}{ccccc}
\hline & \multicolumn{2}{c}{ Kelas Eksperimen } & \multicolumn{2}{c}{ Kelas Kontrol } \\
\cline { 2 - 5 } & Pre-Test & Post-Test & Pre-Test & Post-Test \\
\hline Mean & 90,78 & 93,76 & 88,30 & 89,77 \\
\hline
\end{tabular}

Menurut hasil pemaparan yang telah dijelaskan pada beberapa tabel sebelumnya, maka kesimpulannya yaitu bahwa penerapan model pembelajaran picture and picture memberikan pengaruh yang lebih baik dalam kegiatan pembelajaran siswa, hal ini dapat dibuktikan dalam tabel di atas yang menunjukkan peningkatan nilai yang lebih banyak pada kelas eksperimen, contohnya yaitu pada rata-rata nilai siswa yang mengalami peningkatan dari 90,78 menjadi 93,76. Untuk kelas kontrol yang tetap menggunakan model pembelajaran konvensional mengalami peningkatan rata-rata juga yaitu dari angka 88,30 menjadi 89,77. Namun peningkatan yang terjadi pada kelas kontrol tidak sebanyak kelas eksperimen.

Selain itu pada saat kegiatan pembelajaran berlangsung, siswa yang berada di kelas eksperimen terlihat lebih aktif akibat diberikan penjelasan materi dengan menggunakan model pembelajaran picture and picture. Lain halnya dengan siswa yang berada di kelas kontrol, mereka terlihat tidak perduli dengan materi yang sedang di ajarkan, bahkan beberapa siswa terlihat kesulitan dalam memahami materi, hal ini dikarenakan peserta didik tidak dilibatkan selama pembelajaran berlangsung, selain itu model yang digunakan lebih berpusat pada guru. Berdasarkan hasil yang telah di uraikan di atas, maka dapat dikatakan bahwa penggunaan model pembelajaran picture and picture memberikan pengaruh kepada yang lebih baik dalam kegiatan pembelajaran siswa di SD pada pembelajaran IPA. Penggunaan model pembelajaran picture and picture terbukti dapat memancing keaktifan, keberanian, dan juga kemampuan berpikir kreatif siswa karena siswa diminta untuk menyusun gambar dan menceritakannya. Jawaban dari masing-masing siswa pada saat 
menjelaskan dan menyurun gambar acak dari model picture and picture pun berbeda-beda. Sehingga apabila terdapat perbedaan antara satu siswa dengan siswa lainnya, maka mereka akan berpikir sesuai pemahaman atau imajinasi mereka masing-masing.

Penelitian ini sejalan dengan hasil penelitian yang sebelumnya telah dilakukan oleh (Dewi \& Wardani, 2020) dimana dalam penelitian tersebut membuktikan bahwa terdapat terdapat pengaruh yang signifikan pada kemampuan berpikir kritis siswa dengan menggunakan model pembelajaran Picture and Picture. Kemampuan berpikir kreatif matematis yang merupakan salah satu kemampuan yang perlu dimiliki dan dikembangkan pada siswa dari tingkat SD sampai tingkat perguruan tinggi. Penerapan metode picture and picture di kelas eksperimen dapat menarik perhatian siswa dan dapat meningkatkan keaktifan siswa dalam pembelajaran sehingga dapat memaksimalkan hasil pembelajaran (Mabruroh et al., 2020).

Adapun keterbatasan yang ditemui dalam penelitian ini yaitu dengan melakukan pembelajaran secara daring melalui aplikasi Google Meet, sehingga ada beberapa kendala yang dihadapi. Pertama yaitu masalah koneksi siswa atau peneliti yang terkadang tidak stabil, sehingga ada yang terlewatkan pada saat pembelajaran. Kedua, karena penelitian dilakukan di Sekolah Dasar maka ada beberapa siswa yang tidak memliki hp, ataupun laptop untuk mengikuti pembelajaran. Salah satu alasannya karena orang tua siswa harus bekerja, sehingga siswa tidak bisa mengakses pembelajaran melalui Google Meet. Ketiga, fokus siswa SD tidak bisa terlalu lama sehingga peneliti harus bisa memancing semangat siswa untuk kembali mengikuti pembelajaran. Keempat, orang tua kurang mengontrol kegiatan anak sehingga ada siswa yang tidak mendengarkan penjelasan materi yang disampaikan. Akibatnya pada saat diberikan soal, siswa tidak bisa menjawab dan orang tua juga kesulitan menjelaskan materi kepada anak-anak.

\section{KESIMPULAN}

Berdasarkan hasil penelitian yang telah dijelaskan pada bagian hasil dan pembahasan, maka kesimpulan yang dapat diambil bahwa model pembelajaran picture and picture memberikan pengaruh terhadap kemampuan berpikir kreatif siswa SD khususnya dalam pembelajaran IPA. Selain itu dengan menggunakan model pembelajaran picture and picture, siswa menjadi lebih aktif pada saat proses pembelajaran berlangsung, meningkatkan keberanian berbicara atau berpendapat, memperkuat daya ingat siswa terhadap pembelajaran, dan juga melatih kemampuan berpikir kreatif siswa.

\section{DAFTAR PUSTAKA}

Agung, K., \& Zarah, P. (2016). Metode Penelitian Kuantitatif. Pandiva Buku.

Anugrahana, A. (2020). Hambatan, Solusi Dan Harapan: Pembelajaran Daring Selama Masa Pandemi Covid19 Oleh Guru Sekolah Dasar. Scholaria : Jurnal Pendidikan Dan Kebudayaan, 10(3), 282-289.

Aslam, Aziz Wahab, A., Syae Purrohman, P., Zulherman, \& Segarawati Ampry, E. (2020). Internet User Behavior And Social Media In Learning. Advances In Social Science, Education And Humanities Research, 526, 50-55.

Asri, S. O. (2019). Kemampuan Berpikir Kritis Dan Kreatif Matematis Melalui Pembelajaran Berbasis Masalah. Journal Of Mathematics Education And Science, 5(1), 20-28.

Dewi, R., \& Wardani, K. (2020). Pengaruh Model Pembelajaran Picture And Pictureditinjau Dari Kemampuan Berpikir Kritis Siswa Sekolah Dasar. Jurnal Basicedu, 4(4), 1066-1074.

Galuh, W. T., Maufuzul, U., Triya, N., \& Achmad, A. H. Z. (2018). Efektifitas Media Becak Dalam Pembelajaran Ipa Untuk Meningkatkan Ketrampilan Berfikir Kritis Siswa Sd/Mi. Jurnal Pendidikan Nusantara, 3(2), 189-195. 
3703 Pengaruh Model Pembelajaran Picture And Picture terhadap Kemampuan Berpikir Kreatif Siswa di Sekolah Dasar - Novita Pratiwi, Aslam

DOI: https://doi.org/10.31004/edukatif.v3i6.1081

Handarini, O. (2020). Pembelajaran Daring Sebagai Upaya Study From Home (Sfh) Selama Pandemi Covid 19. Jurnal Pendidikan Administrasi Perkantoran (Jpap), 8(3), 496-503.

Hanna, S. (2015). Model-Model Pembelajaran Dan Pemefolehan Bahasa Kedua/Asing. Jurnal Pujangga, 1(2), $106-117$.

Ida, F. (2016). Model Pembelajaran Kooperatif Dan Implikasinya Pada Pemahaman Belajar Sains Di Sd/Mi (Studi Ptk Di Kelas Iii Min 3 Watesliwa Lampung Barat). Jurnal Pendidikan Dan Pembelajatran Dasar, $3(2), 1-22$.

Jariah. (2016). Upaya Meningkatkan Hasil Belajar Siswa Melalui Model Picture And Picture Pada Materi Penyesuaian Hewan Dengan Lingkungannya Di Sd Negeri 11 Sungai Putat Kabupaten Sanggau. Jurnal Penelitian Guru Pendidikan Ilmu Pengetahuan Alam, 1(1), 35-49.

Lufri, Ardi, Yogica, R., Muttaqiin, A., \& Fitri, R. (2020). Metodologi Pembelajaran : Strategi, Pendekatan, Model, Metode Pembelajaran. Cv Irdh.

Lulu, R. A., Kisyani, L., \& Wahyu, S. (2016). Kemampuan Berpikir Kreatif Dalam Menulis Naratif Siswa Kelas V Sekolah Dasar Negeri Di Kecamatan Gayungan Surabaya. Jurnal Review Pendidikan Dasar: Jurnal Kajian Pendidikan Dan Hasil Penelitian, 2(2), 166-174. Http://Journal.Unesa.Ac.Id/Index.Php/Pd

Mabruroh, L., Irianto, A., \& Yustitia, V. (2020). Pengaruh Metode Picture And Picture Terhadap Berpikir Kreatif Siswa Sekolah Dasar. Jurnal Pendidikan Dasar, 11(102-108).

Rigianti, H. (2020). Kendala Pembelajaran Daring Guru Sekolah Dasar Di Kabupaten Banjarnegara. 7(2), 297-302.

Siti, F., Ely, R. S., \& Widyanti, N. (2020). Pengaruh Model Pembelajaran Picture And Picture Terhadap Hasil Belajar Geografi. 34(1), 19-28. Https://Doi.Org/Doi.Org/10.21009/Pip.341.3

Suardi, M. (2018). Belajar Dan Pembelajaran. Deepublish.

Sugiyono. (2013). Metode Penelitian Kuantitatif, Kualitatif, Dan R\&D. Alfabeta.

Suhery, Putra, T., \& Jasmalinda. (2020). Sosialisasi Penggunaan Aplikasi Zoom Meeting Dan Google Classroom Pada Guru Di Sdn 17 Mata Air Padang Selatan. Jurnal Inovasi Penelitian, 1(3), 129-132.

Sulthon. (2016). Pembelajaran Ipa Yang Efektif Dan Menyenangkan Bagi Siswa Madrasah Ibtidaiyah (Mi). $4(1), 39-54$.

Veroneka, U. (2020). Pengaruh Penerapan Model Pembelajaran Picture And Picture Terhadap Minat Dan Keaktifan Siswa Kelas Xi Ipa Pada Pembelajaran Biologi. Universitas Islam Negeri Sulthan Thaha Saifuddin Jambi.

Widyawati, W. (2019). Keefektifan Model Pembelajaran Picture And Picture Dalam Keterampilan Menulis Untuk Tingkat Universitas. Jurnal Kredo, 2(2), 226-241.

Wiyati. (2018). Penerapan Model Pembelajaran Picture And Picture Untuk Meningkatkan Kemampuan Membaca Permulaan Siswa Kelas I Sekolah Dasar. Jurnal Primary Program Studi Pendidikan Guru Sekolah Dasar Fakultas Keguruan Dan Ilmu Pendidikan Universitas Riau, 7(1), 88-95.

Yusuf, W. (2018). Implementasi Kurikulum 2013 (K-13) Pada Mata Pelajaran Pendidikan Agama Islam Sekolah Dasar (Sd). Jurnal Al-Murabbi, 3(263-278). 